\title{
Life cycle inventory for use of waste solvent as fuel substitute in the cement industry A multi-input allocation model
}

\author{
Journal Article \\ Author(s): \\ Seyler, Christina; Hellweg, Stefanie; Monteil, Michel; Hungerbühler, Konrad \\ Publication date: \\ 2005-03 \\ Permanent link: \\ https://doi.org/10.3929/ethz-b-000033665
}

Rights / license:

In Copyright - Non-Commercial Use Permitted

Originally published in:

The International Journal of Life Cycle Assessment 10(2), https://doi.org/10.1065/lca2004.08.173 


\title{
LCA Methodology
}

\section{Life Cycle Inventory for Use of Waste Solvent as Fuel Substitute in the Cement Industry} A Multi-Input Allocation Model

\author{
Christina Seyler ${ }^{1}$, Stefanie Hellweg ${ }^{1 *}$, Michel Monteil ${ }^{2}$ and Konrad Hungerbühler \\ ${ }^{1}$ Institute for Chemical- and Bioengineering, Swiss Federal Institute of Technology, ETH-Hönggerberg, CH-8093 Zürich, Switzerland \\ 2 Holcim (Schweiz) AG, Zementweg 1, CH-5305 Würenlingen
}

$\overline{* \text { Corresponding author }}$ (stefanie.hellweg@chem.ethz.ch)

DOI: http://dx.doi.org/10.1065/lca2004.08.173

\section{Abstract}

Background. The Swiss chemical industry produces large amounts of organic waste solvents. Some of these solvents cannot be recovered. A common option for the treatment of such organic waste solvents is the incineration in hazardous waste incinerators. Alternatively, the waste solvents can be used as fuel in cement production. On the one hand, solvent incineration in cement kilns saves fossil fuels such as coal and heavy fuel oil. On the other hand, fuel-bound emissions may change as well. These emission changes can either have a negative or a positive net ecological impact, depending on the chemical nature of the waste solvent used.

Goal and Scope. The aim of our work was to develop a multiinput allocation model, which allows one to calculate life cycle inventories for specific waste solvents. These LCIs can then be used in further applications, e.g. a comparison of different waste solvent treatment options.

Results and Discussion. A multi-input allocation model was developed that takes into account the physico-chemical properties of waste solvents such as elementary composition and net calorific value. The model is based on a set of equations and data on fuel mix, fuel composition as well as transfer coefficients for heavy metals. The model calculates 'avoided inputs' and 'changes in emissions' which arise from substituting fossil fuels with waste solvents. Life cycle inventories can be calculated for specific waste solvents if the elementary composition and the net calorific value are known. The application of the model is illustrated in a case study on four waste solvents. The results show that solvent incineration in cement kilns generally reduces the overall impact of clinker production because fossil fuels are replaced. A sensitivity analysis revealed that the model is especially sensitive to the fuel mix and coal properties, such as net calorific value as well as the content of nitrogen and carbon. The transfer coefficients are also uncertain, but this uncertainty is not relevant as the amount of heavy metal emitted into the atmosphere is small.

Conclusions and Outlook. The proposed model serves to calculate inventory data for the combustion of liquid alternative fuels such as waste solvents in cement kilns. Although our model represents Swiss cement production conditions, it can be applied to other countries by fitting the most sensitive parameters of fuel mix and coal properties. In case the technology used is very different to the Swiss situation, the transfer coefficients also need to be adapted.

Keywords: Alternative fuel; cement manufacturing; clinker production; fuel substitution; inventory model; life cycle inventory; multi-input allocation; waste solvent

\section{Introduction}

The Swiss chemical industry produces large amounts of organic waste solvents every year. These solvents can often not be re-used in chemical production processes because of quality, logistic and economic reasons [1]. Organic waste solvents that cannot be regenerated are generally incinerated [2]. The largest part of these waste solvents is treated in special waste solvent incinerators. In this process, the impurities are transferred, depending on their physicochemical nature, into air, water or hydroxide sludge. This transfer of impurities into different environmental compartments (atmosphere, river, landfill) causes environmental impacts. Besides those impacts, most of the organic waste solvents have a high energy content, which is usually recovered in the incineration process and used for steam and electricity production [2]. This aspect causes an environmental benefit as fossil fuels are saved. A model has been set up to assess the environmental impacts of such incineration processes depending on the specific properties of the waste solvents [2].

Waste solvents which are only contaminated to a small extent can also be incinerated in a cement kiln. There, they serve as alternative fuels replacing fossil fuels such as coal and heavy fuel oil. When substituting fossil fuels by waste solvents, environmental impacts occur and/or are avoided similarly to the waste solvent incineration process described above. To assess those impacts, we propose a multi-input allocation model which takes into account the properties of the specific waste solvents. With this multi-input allocation model, tailor-made life cycle inventories (LCI) can be calculated for every waste solvent. Those LCIs can then be used to assess the specific environmental burdens/benefits which arise when substituting fossil fuels in the cement manufacturing with a specific waste solvent.

Our model depicts the cement manufacturing situation in Switzerland, but the transferability to other geographical regions with other technologies and fuels is also discussed in this article. Our approach can be used in combination with a model for waste solvent incineration [2] that has been developed within the same project. Such a joint application may allow assessing and comparing different treatment options for waste solvents. 


\section{Waste Solvent Incineration in the Swiss Cement Industry}

\subsection{Use of waste solvents as alternative fuel in the cement industry}

The Swiss cement industry produces nearly 4 million $\mathrm{t}$ cement per year [3]. The manufacturing of cement is very energy intensive. The energy requirement lies between 4200 and $5000 \mathrm{MJ} / \mathrm{t}$ of cement [4], whereof about $3500 \mathrm{MJ} / \mathrm{t}$ is thermal energy used in the high temperature clinker burning process (see Fig. 2 in Section 1.2) [5]. Energy carriers have traditionally been fossil fuels such as coal and heavy fuel oil. More and more different kinds of wastes such as waste oil, dried sewage sludge, plastic wastes or waste solvents are used as alternative fuels in the cement industry. In 2002 , the share of alternative fuels amounted to $47.8 \%$ of the total thermal energy consumption. This fraction is supposed to increase even more in future [3]. In Fig. 1, the development of the fuel consumption in the Swiss cement industry is shown for the years 1996 to 2002.

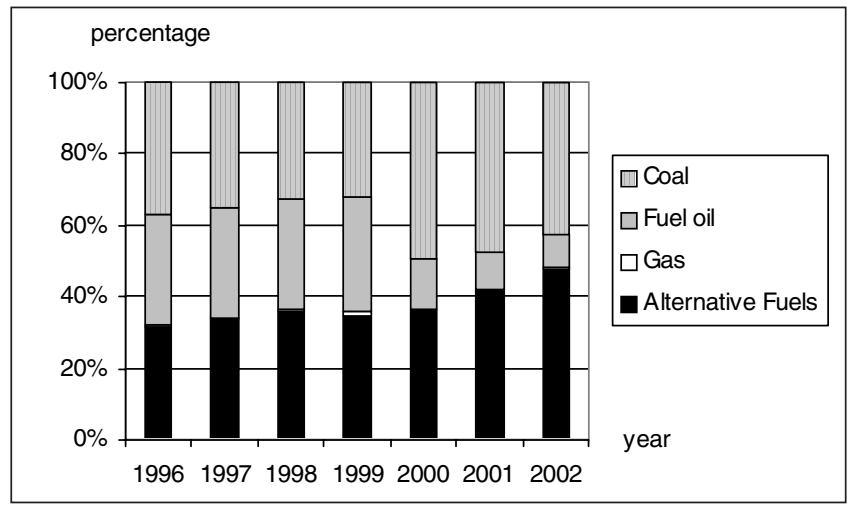

Fig. 1: Fuels used in Swiss cement industry [3]

Waste solvent is a welcome alternative fuel for the cement industry. It is comparably pure, easy to handle and it usually has a high energy content. The consumption of waste solvent and distillation residues in the Swiss cement industry was approximately 30,600 t/a in 2002, which is a share of $13.6 \%$ of the total of alternative fuels [3]. This share has been relatively constant in the last five years.

The use of wastes as alternative fuels in the cement industry is strongly regulated in Switzerland. To ensure that the treatment of wastes in cement manufacturing plants is 'ecologically meaningful' (e.g. the waste is really used for fuel substitution, does not lead to a dilution of contaminants, does not cause any ecological follow-up problems), guidelines were set up that have to be followed by the cement industry [6]. According to these guidelines, alternative fuels such as waste solvents must meet the limiting values of Table 1.

Table 1 only lists the data relevant to our model (for further information see [6]). The values in Table 1 refer to wastes with a net calorific value of $25 \mathrm{MJ} / \mathrm{kg}$ and have to be converted correspondingly for wastes with different net calorific values. In this paper, the term heating value always refers to the net calorific value. There is a second set of limiting
Table 1: Limiting values for the content of pollutants in wastes that are used as alternative fuels in cement industry in Switzerland [6]

\begin{tabular}{l|c}
\hline Element & $\begin{array}{c}\mathbf{m g} / \mathbf{k g} \text { (referring to a } \text { net } \\
\text { calorific value of } \mathbf{2 5} \mathbf{~ M / k g})\end{array}$ \\
\hline $\mathrm{As}$ & 15 \\
\hline $\mathrm{Cd}$ & 2 \\
\hline $\mathrm{Cr}$ & 100 \\
\hline $\mathrm{Cu}$ & 100 \\
\hline $\mathrm{Hg}$ & 0.5 \\
\hline $\mathrm{Ni}$ & 100 \\
\hline $\mathrm{Pb}$ & 200 \\
\hline $\mathrm{Tl}$ & 3 \\
\hline $\mathrm{Zn}$ & 400 \\
\hline Organically bound halogens & $<1 \mathrm{w} \%$ \\
\hline
\end{tabular}

values that restrict the content of pollutants in the final cement product [6]. Those limiting values ensure, on the one hand, the technical quality of the cement (e.g. solidification behaviour). On the other hand, they define tolerable limits of pollutants in the cement in order to protect humans and the environment. If these limiting values (not listed in this paper) are exceeded in the final cement product, the mass flow of the wastes used in the production process must be reduced.

For technical reasons (e.g. accumulation of certain elements in the kiln, corrosion), the cement manufacturing plants additionally have internal standards for the use of alternative fuels. In Table 2 the standards from Holcim AG, which is the leading Swiss cement producer, are given for liquid alternative fuels [7]. Other companies can have different standards depending on process and raw material [8].

Table 2: Limiting values for liquid alternative fuels from the internal technical standards of Holcim AG [7]

\begin{tabular}{l|c}
\hline Net calorific value & $>\mathbf{1 8 ~ M J / k g}$ \\
\hline Particles & $<2 \mathrm{~mm}$ \\
\hline $\mathrm{pH}$ & $>5$ \\
\hline$\sum$ Halogens & $<1 \mathrm{w} \%$ \\
\hline $\mathrm{S}$ & $<1 \mathrm{w} \%$ \\
\hline $\mathrm{H}_{2} \mathrm{O}$ & $<15 \mathrm{w} \%$ \\
\hline
\end{tabular}

Tables 1 and 2 illustrate that the spectrum for possible wastes is rather narrow. Nevertheless, waste solvents from the Swiss chemical industry usually meet these standards as they are only contaminated to a small extent [2] (this, of course, is not the case for halogenated solvents). For illustration, the average composition of the waste solvents used in the Swiss plants of Holcim AG in the year 2001 is given in Table 3 (detailed data were only available for one plant but the solvents incinerated in other plants have similar compositions). Also for comparison, the composition of the waste solvent mixture incinerated in a special waste solvent incineration plant in the chemical industry is given [2]. These data have been averaged for the years 1998 to 2001 . 
Table 3: Typical composition of waste solvent incinerated in the Swiss plants of Holcim AG and average composition of waste solvents incinerated in a waste solvent incineration plant in chemical industry. Values in percentage are percentage by weight. n.a.: data not available, n.d.: not detectable

\begin{tabular}{|c|c|c|c|}
\hline Substance / NCV & Unit & Waste solvent in cement manufacturing plant & $\begin{array}{l}\text { Waste solvent in waste solvent } \\
\text { incineration plant }\end{array}$ \\
\hline C & $\%$ & n.a. & 47.7 \\
\hline $\mathrm{H}$ & $\%$ & n.a. & $8.2^{a)}$ \\
\hline 0 & $\%$ & n.a. & ca. $20^{\text {a), b) }}$ \\
\hline $\mathrm{H}_{2} \mathrm{O}$ & $\%$ & 10.3 & 16.5 \\
\hline $\mathrm{N}$ & $\%$ & n.a. & 1.0 \\
\hline $\mathrm{S}$ & $\%$ & n.a. & 0.7 \\
\hline $\mathrm{P}$ & $\%$ & n.a. & 0.06 \\
\hline $\mathrm{Cl}$ & $\%$ & 0.32 & 2.4 \\
\hline $\mathrm{Br}$ & ppm & 200 & 2500 \\
\hline 1 & ppm & n.a. & 130 \\
\hline As & ppm & 2 & n.d. \\
\hline $\mathrm{Cd}$ & ppm & 0.1 & n.d. \\
\hline Co & ppm & 2.5 & 4.1 \\
\hline $\mathrm{Cr}$ & ppm & 1.9 & n.d. \\
\hline $\mathrm{Cu}$ & ppm & 4.1 & 6.2 \\
\hline $\mathrm{Fe}$ & ppm & n.a. & 85 \\
\hline $\mathrm{Hg}$ & ppm & 0.1 & n.d. \\
\hline $\mathrm{Ni}$ & ppm & 2.1 & 4.6 \\
\hline $\mathrm{Pb}$ & ppm & 2.6 & n.d. \\
\hline $\mathrm{TI}$ & ppm & 0.5 & n.d. \\
\hline $\mathrm{Zn}$ & ppm & 18 & 57 \\
\hline Net calorific value & $\mathrm{MJ} / \mathrm{kg}$ & 26.5 & 21.7 \\
\hline
\end{tabular}

a) Without elements bound in water.

b) The content of oxygen is not measured. The mass balance gives that the sum of oxygen and rest (alkaline metals) must be $23.1 \%$.

\subsection{Technology description of cement manufacturing}

The core process in cement manufacturing is the pyroprocessing of raw materials containing mainly calcium carbonates and silica to produce clinker (e.g. [9]). The clinker amounts to about $95 \%$ of the cement. The cement manufacturing process is schematically shown in Fig. 2. The raw materials of limestone and marl extracted by mining (1) are transported to the cement plant where they are ground and dried (2) to produce the raw meal. Alumina and iron oxides may be added as additives. The raw meal is then preheated by hot kiln gases (3) before it is inserted into the rotary kiln (4). In the rotary kiln the raw meal is calcined and sintered at temperatures up to $1450^{\circ} \mathrm{C}$ (flame temperature $2000^{\circ} \mathrm{C}$ ) to yield the clinker. Large amounts of coal, heavy fuel oil or alternative fuels are used to create these high temperatures. After cooling (6), the clinker produced is mixed with additives such as gypsum and ground into cement in the finishing mill (7). This part of the process does not need any thermal energy and is therefore not taken into account in this study. From now on we will therefore talk about clinker rather than cement production.

Usually rotary kiln technology is used for clinker production (except for China and India where vertical shaft kilns are more common [10]). The process is further differentiated in wet, semi-wet, semi-dry and dry processes [9]. In Switzerland, five dry processes (suspension preheater kilns) with a total of 3,220,000 t/a capacity and four semi-dry processes (Lepol kilns) with a total of 820,000 t/a capacity were in operation in 2002 [3].

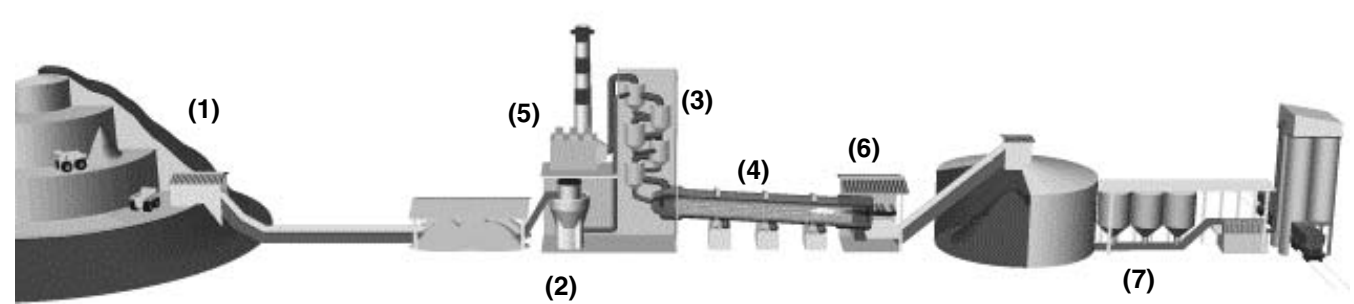

Fig. 2: Scheme of the cement manufacturing process [7] 
All of the clinker production plants operating in Switzerland have flue gas cleaning technologies such as electrostatic precipitators or bag filters (5). Some also have $\mathrm{SO}_{2}$-removal technologies such as wet scrubbers, DENOX equipment such as selective non-catalytic reduction (SNCR), or active coke filters. The installation of those special flue gas cleaning devices is rather a function of the raw material properties (e.g. sulphur content of the rock) and does not reflect the 'degree of modernity' of a plant [5]. The flue gas cleaning technologies are not affected by the kind of fuel used and were therefore not modelled separately in our model.

There are only two output streams from the clinker production process: clinker and flue gas that is released into the atmosphere after having passed the flue gas cleaning. Ashes, arising from the fuel incineration process, are completely incorporated in the clinker. Residues from flue gas cleaning (filter dust, gypsum, active coke) are re-fed into the rotary kiln.

\section{Model Decisions and Used Model Data}

\subsection{Technology model}

The model developed in this paper shall represent the Swiss cement manufacturing landscape. Single plants are not of interest as the model will not deal with the incineration of waste solvents in specific plants. Therefore, the best model would have been an average of all existing Swiss clinker production plants. As it was not possible to get data for all clinker production plants in Switzerland (in 2002, four companies were operating eight clinker production plants in Switzerland [3]), we focused on the kilns of Holcim AG (five plants). These kilns cover $55 \%$ of the total Swiss clinker capacity and 59\% of the total amount of waste solvent used in 2002, and are therefore a reasonable representation of the Swiss clinker production situation. Three of the Holcim kilns are suspension preheater kilns (total capacity of 1,970,000 t/a), two of them are Lepol kilns (total capacity of 400,000 t/a). The plants included in our study are listed in Table 4.

Furthermore, we assume that the waste solvent only substitutes fossil fuels (coal and heavy fuel oil) and that there is no substitution of other alternative fuels used. In rare cases there are substitutions of alternative fuels, e.g. the substitution of animal meal by sewage sludge [7]. As this is performed because of raw material composition reasons (sewage sludge, for example, contains less of the compound $\mathrm{P}_{2} \mathrm{O}_{5}$ which is critical to the technical process), we will not consider substitutions of alternative fuels in this paper. The base case for our model is the substitution of coal and heavy fuel oil ac- cording to the fuel mix used in the Swiss Holcim plants (see Table 5). In reality, however, heavy fuel oil is often substituted first for economic reasons. Only when there is no fuel oil left is coal substituted as well. This case will be looked at for sensitivity contemplation (Section 4.4).

Fuel substitution can affect the total energy consumption of the process. Some of those effects are included in our model; those of minor importance are neglected. When waste solvent is used instead of fossil fuels, there might be a change in total electricity consumption. This is due to the electricity consumption for grinding the coal, for example, which is no longer necessary when using waste solvents instead. Another change might occur from an increase/decrease in the flue gas volume (per energy unit) when using a fuel substitute. The flue gas volume influences the electricity consumption of the suction fan. In our model, though, we neglect the influence of fuel substitution on electricity consumption. There might also be an effect on total thermal energy consumption of the process when using waste solvents instead of fossil fuels. Thermal energy is e.g. used for drying the coal or for pre-heating the heavy fuel oil. This energy is not necessary when using waste solvents as fuel. This change in thermal energy consumption (or total energy efficiency of the process) is not modelled either as it is assumed to be of minor importance. On the contrary, the influence of the water content of the waste solvents on energy use is considered. Studies on the use of dried sewage sludge as alternative fuels in the cement industry [11] have shown that the influence of heating the water contained in the alternative fuels may be significant. Holcim AG uses a corrective factor that takes into account the reduction in energy efficiency for wastes with high water content. This aspect is included in our model.

Furthermore, we assume the fuel substitution does not affect any raw material input. In reality, raw materials and fuels have to be matched to meet the defined clinker specification. If large amounts of coal were substituted by waste solvents, for instance, there would be an extra need of mineral materials which otherwise would have been brought in by the ash of the coal. Such effects on raw material input are not included in our model.

Last, we assume the clinker quality is not affected by fuel substitution. However, a change in clinker composition should be taken into account when modelling the influence of the disposal of cement used (e.g. after deconstruction of a building) in a landfill. This will be done in a sensitivity analysis in Section 4.4.

Table 4: Technological description of the five clinker production plants operated by Holcim AG in Switzerland in 2002

\begin{tabular}{l|c|c|c}
\hline Plant name & Capacity in ta & Kiln technology & Flue gas treatment technology \\
\hline Brunnen & 150,000 & Lepol & Electrostatic precipitator \\
\hline Eclepens & 530,000 & Suspension preheater & Bag filter, DENOX \\
\hline Siggenthal & 620,000 & Suspension preheater & Electrostatic precipitator, DENOX, active coke filter \\
\hline Thayngen & 250,000 & Lepol & Electrostatic precipitator, DENOX \\
\hline Untervaz & 820,000 & Suspension preheater & Electrostatic precipitator, DENOX dry scrubber \\
\hline
\end{tabular}




\subsection{Fuel mix and fuel composition}

For our model, we need information on the fuel mix and on the fuel composition. Data used in our model mainly stem from the five plants under study. Where no data was available from Holcim AG, we completed it by using published data. Data on the fuel mix were available for the years 2000 to 2002 for all five plants. An average was calculated over the five plants and over the three years, and is given in Table 5. The minimum and maximum values are given as further information to allow sensitivity calculations. Furthermore, the average heating values for the coal and heavy fuel oil, as well as the minimum and maximum values, are presented in Table 5. Data for the composition of coal and heavy fuel oil used for clinker production are presented in Table 6.

\subsection{Transfer coefficients for heavy metals}

Changes in heavy metal emissions, which may occur by fuel substitution, are modelled with the help of transfer coefficients. We use the general definition for transfer coefficients (Eq. 1), which was described, for example, in [16]:

$\mathrm{tc}_{\mathrm{i}, \mathrm{j}}=\frac{\mathrm{A}_{\mathrm{i}, \mathrm{j}}}{\mathrm{A}_{\mathrm{i}, \mathrm{w}}}$

where

$\mathrm{tc}_{\mathrm{i}, \mathrm{j}}$ is the transfer coefficient of the element $\mathrm{i}$ to the output $\mathrm{j}$; tc is dimensionless,

$A_{i, j}$ is the element flow of element $i$ via the output $j$ in $\mathrm{kg} / \mathrm{a}$, $A_{i, w}$ is the element flow of element $i$ via the waste input in $\mathrm{kg} / \mathrm{a}$.
As described above, there are only two mass streams that have to be taken into account in the clinker production process: clinker and flue gas. This gives a simple model for the transfer processes (Fig. 3). Accordingly, only two transfer coefficients were calculated: $t c_{i}$, flue gas for the flue gas and $t c_{i}$, ${ }_{\text {clinker }}$ for the clinker. The relation $\mathrm{tc}_{\mathrm{i}}$, flue gas $+\mathrm{tc}_{\mathrm{i} \text {, clinker }}=1$ holds.

Transfer coefficients were received from Holcim AG from the five plants under study. The coefficients are based on measurement data of several years prior to 2002 . The transfer coefficients for every element were averaged over the

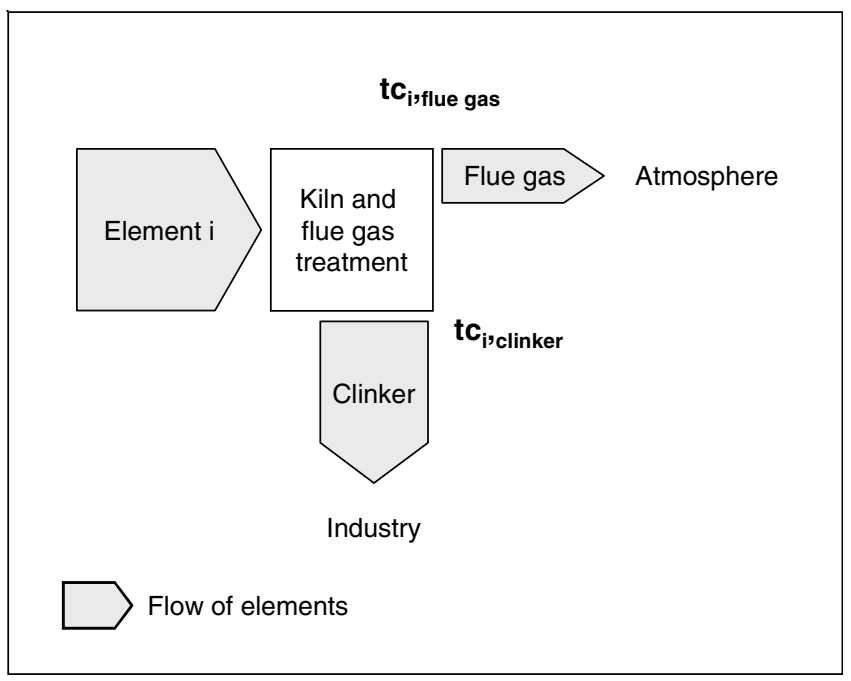

Fig. 3: Transfer model for the clinker production process

Table 5: Fuel mix and net calorific values for the five Holcim AG plants in the years 2000 to 2002

\begin{tabular}{l|c|c|c}
\hline Fuel mix [weight\%] & Average & Min & Max \\
\hline Coal & 50.0 & 20.2 & 70.4 \\
\hline Heavy Fuel Oil & 9.0 & 0 & 23.0 \\
\hline Alternative Fuels & 41.0 & 11.5 & 68.6 \\
\hline Net calorific value $[\mathrm{MJ} / \mathrm{t}]$ & Average & Min & Max \\
\hline Coal & 25,793 & 23,220 & $33,040^{\text {a) }}$ \\
\hline $\begin{array}{l}\text { Heavy Fuel Oil } \\
\text { a) The high maximum value is due to the use of pet coke in one of the plants. Pet coke is not looked at separately in our model but treated as a fossil } \\
\text { fuel equal to coal. }\end{array}$
\end{tabular}

Table 6: Composition of heavy fuel oil and coal used in this paper [5]. For heavy fuel oil no minimum or maximum values were available. n.a.: not available, n.d.: not detectable

\begin{tabular}{|c|c|c|c|c|c|}
\hline \multirow[t]{2}{*}{ Composition } & \multirow[t]{2}{*}{ Unit } & \multicolumn{3}{|c|}{ Coal } & \multirow{2}{*}{$\begin{array}{c}\text { Heavy fuel oi } \\
\text { Average }\end{array}$} \\
\hline & & Average & Min & Max & \\
\hline $\mathrm{C}$ & $\%$ & $73^{a)}$ & & & $84^{b)}$ \\
\hline $\mathrm{N}$ & $\%$ & $1.3^{c)}$ & n.a. & n.a. & $0.44^{d)}$ \\
\hline $\mathrm{S}$ & $\%$ & n.a. & n.a. & n.a. & $0.83^{\mathrm{e})}$ \\
\hline $\mathrm{P}$ & $\%$ & n.a. & n.a. & n.a. & Traces $^{\text {d) }}$ \\
\hline Halogens & $\mathrm{g} / \mathrm{t}$ & n.a. & n.a. & n.a. & $\begin{array}{c}\text { Cl: } 20^{\text {d) }} \\
\text { others: n.d. }\end{array}$ \\
\hline As & $\mathrm{g} / \mathrm{t}$ & 30 & 9 & 50 & 0.8 \\
\hline $\mathrm{Cd}$ & $\mathrm{g} / \mathrm{t}$ & 0.24 & 0.1 & 10 & 2 \\
\hline $\mathrm{Cr}$ & $\mathrm{g} / \mathrm{t}$ & 43 & 5 & 80 & 1 \\
\hline $\mathrm{Cu}$ & $\mathrm{g} / \mathrm{t}$ & 37 & 30 & 44 & 3 \\
\hline $\mathrm{Hg}$ & $\mathrm{g} / \mathrm{t}$ & 0.42 & 0.1 & 3.3 & 0.006 \\
\hline $\mathrm{Ni}$ & $\mathrm{g} / \mathrm{t}$ & 50 & 20 & 80 & $15^{\mathrm{e})}$ \\
\hline $\mathrm{Pb}$ & $\mathrm{g} / \mathrm{t}$ & 140 & 11 & 270 & 3.5 \\
\hline $\mathrm{TI}$ & $\mathrm{g} / \mathrm{t}$ & 0.63 & 0.2 & 4.0 & n.d. ${ }^{d)}$ \\
\hline $\mathrm{Zn}$ & $\mathrm{g} / \mathrm{t}$ & 118 & 16 & 220 & $0.9^{\text {d) }}$ \\
\hline
\end{tabular}


Table 7: Transfer coefficients for the transfer of heavy metals from fuel into flue gas ( $\mathrm{tc}_{\mathrm{i}}$,flue gas $)$. The transfer coefficients from the five plants under study (Table 4) were averaged. The minimal and the maximal values are also given

\begin{tabular}{l|c|c|c}
\hline Elements / Transfer coefficients [\%] & Average & Min & Max \\
\hline $\mathrm{As}^{\text {a) }}$ & 0.01 & 0 & 0.01 \\
\hline $\mathrm{Cd}$ & 4.32 & 0 & 7.35 \\
\hline $\mathrm{Cr}$ & 0.01 & 0 & 0.02 \\
\hline $\mathrm{Cu}$ & 0.01 & 0 & 0.02 \\
\hline $\mathrm{Hg}$ & 24.96 & 0 & 46.4 \\
\hline $\mathrm{Ni}{ }^{1)}$ & 0.001 & 0 & 0.002 \\
\hline $\mathrm{Pb}$ & 0.21 & 0 & 0.64 \\
\hline $\mathrm{Tl}$ & 2.81 & 0 & 6.13 \\
\hline $\mathrm{Zn}$ & 0.18 & & 0.85 \\
\hline${ }^{\mathrm{a})}$ Data taken from [17] & & & \\
\hline
\end{tabular}

five plants to give an average transfer coefficient. Where no data were available from Holcim (arsenic, nickel), data were taken from [17]. In Table 7, the coefficients for the transfer of heavy metals into the flue gas are given. We have not listed the transfer coefficients for the clinker as they can be calculated easily from the flue gas coefficients $\left(\mathrm{tc}_{\mathrm{i}, \text { clinker }}=1-\mathrm{tc}_{\mathrm{i} \text {, flue gas }}\right)$.

\section{Model Description}

The multi-input allocation method presented in this paper calculates the savings of fossil fuels and the changes in atmospheric emissions, which result from the substitution of fossil fuels by waste solvents. Input parameters for the method are the properties of the waste solvent under study such as amount, net calorific value and elementary composition. The result of the calculation is an LCI for a specific waste solvent that is used as an alternative fuel in a clinker production process. In Section 3.1, the amounts of fossil fuels substituted by waste solvents are calculated. They are listed as 'avoided input' in the LCI (see Table 9 in Section 4.2). In Section 3.2, the changes in the atmospheric emissions that are caused by the substitution of fossil fuels are calculated. They are listed as 'changes in output' in the LCI.

\subsection{Savings of fossil fuels}

The savings of fossil fuels are calculated with a heat balance. It is assumed that the amount of energy introduced by the waste solvent substitutes the equal amount of energy which otherwise would have been provided by the conventional fuel mix, i.e. coal and heavy fuel oil (Eq. 2). The proportion of coal to oil is assumed to remain constant (Eq. 3).

$\mathrm{M}_{\text {waste solvent }}$ * $\mathrm{NCV}_{\text {waste solvent }}=\mathrm{M}_{\text {fuel oil }}$ * $\mathrm{NCV}_{\text {fuel oil }}$

$+\mathrm{M}_{\text {coal }} * \mathrm{NCV}_{\text {coal }}$

$\mathrm{M}_{\text {coal }} / \mathrm{M}_{\text {fuel oil }}=\mathrm{P}_{\text {coal }} / \mathrm{P}_{\text {fuel oil }}=$ constant, for $\mathrm{P}_{\text {fuel oil }}$

and $\mathrm{P}_{\text {coal }} \neq 0$

where

$M$ is the mass of fuel in $t$,

$\mathrm{NCV}$ is the net calorific value in $\mathrm{MJ} / \mathrm{t}$ and

$\mathrm{P}$ is the proportion in the original (fossil) fuel mixture in $\%$.
The amount of coal and fuel oil saved can be calculated by combining Eq. 2 and 3 (Eq. 4 and 5):

$\mathrm{M}_{\text {coal }}=\left(\mathrm{M}_{\text {waste solvent }} * \mathrm{NCV}_{\text {waste solvent }}\right) /\left(\mathrm{NCV}_{\text {coal }}\right.$

$\left.+\mathrm{P}_{\text {fuel oil }} / \mathrm{P}_{\text {coal }} * \mathrm{NCV}_{\text {fuel oil }}\right)$

$\mathrm{M}_{\text {fuel oil }}=\mathrm{M}_{\text {coal }} * \mathrm{P}_{\text {fuel oil }} / \mathrm{P}_{\text {coal }}$

In the case one wants to calculate the substitution of heavy fuel oil, only $\left(\mathrm{M}_{\text {coal }}=0\right)$ or coal only $\left(\mathrm{M}_{\text {fuel oil }}=0\right) \mathrm{Eq} .2$ simplifies to Eq. 6 and 7, respectively:

$\mathrm{M}_{\text {fuel oil }}=\left(\mathrm{M}_{\text {waste solvent }} * \mathrm{NCV}_{\text {waste solvent }}\right) / \mathrm{NCV}_{\text {fuel oil }}$

$\mathrm{M}_{\text {coal }}=\left(\mathrm{M}_{\text {waste solvent }} * \mathrm{NCV}_{\text {waste solvent }}\right) / \mathrm{NCV}_{\text {coal }}$

If the waste solvent contains water, some of the energy will be 'lost' for heating and evaporating this water in the kiln (note: This must only be considered when the water content is not included in the heating value, which would be the case when the heating value is calculated by an approximation formula, e.g. with the formula of Dulong [14]). This aspect is considered in our model by calculating an effective, net calorific value $\mathrm{NCV}_{\text {eff }}$, that represents the effective amount of energy at disposal for clinker production. For this purpose, Holcim AG uses a corrective factor of 2500 MJ per tonne of water [7]. This factor includes the heating and evaporation of water. The effective net calorific value is calculated with Eq. 8:

$\mathrm{NCV}_{\text {waste solvent, eff }}=\mathrm{NCV}_{\text {waste solvent }}-\mathrm{M}_{\mathrm{H} 2 \mathrm{O}} / \mathrm{M}_{\text {waste solvent }}$

*2500 MJ/t

where $\mathrm{M}_{\mathrm{H} 2 \mathrm{O}}$ is the mass of water in $\mathrm{t} / \mathrm{t}$ waste solvent.

For waste solvents that contain water, $\mathrm{NCV}_{\text {waste solvent, eff }}$ should be used in the equations given above instead of $\mathrm{NCV}_{\text {waste solvent }}$. 


\subsection{Changes in atmospheric emissions}

One of the most important emissions in the clinker production process is $\mathrm{CO}_{2}$. About $40 \%$ of the $\mathrm{CO}_{2}$ production in the clinker production process originate from the incineration of fuel, about $60 \%$ come from the calcination of the raw material [4]. When substituting conventional fuel with waste solvents, a change in $\mathrm{CO}_{2}$ emission can occur due to different carbon contents per heating value. The 'delta'- $\mathrm{CO}_{2}$ emissions created can either be negative or positive, depending on the carbon content of the waste solvent. In our model we calculate $\mathrm{CO}_{2}$ emissions from the carbon contents of the fuels, assuming a $100 \%$ conversion from $\mathrm{C}$ to $\mathrm{CO}_{2}$. Eq. 9 quantifies the change in $\mathrm{CO}_{2}$ emission $\left(\Delta \mathrm{CO}_{2}\right.$ in $\left.\mathrm{kg} \mathrm{CO}_{2}\right)$ considering that $1 \mathrm{~kg}$ of $\mathrm{C}$ gives $3.67 \mathrm{~kg}$ of $\mathrm{CO}_{2}$ stoichiometrically.

$$
\begin{aligned}
& \Delta \mathrm{CO}_{2}=\left(\mathrm{M}_{\text {waste solvent }} * \mathrm{C}_{\text {waste solvent }}-\mathrm{M}_{\text {coal }} * \mathrm{C}_{\text {coal }}\right. \\
& \left.-\mathrm{M}_{\text {fuel oil }} * \mathrm{C}_{\text {fuel oil }}\right) * 3.67
\end{aligned}
$$

where

$M$ is the mass in $t$ and

$\mathrm{C}$ is the carbon content in $\mathrm{kg} \mathrm{C} / \mathrm{t}$ fuel.

Another important emission in the clinker production process is $\mathrm{NO}_{\mathrm{x}} \cdot \mathrm{NO}_{\mathrm{x}}$ mainly originates from oxidation of the atmospheric nitrogen (thermal $\mathrm{NO}_{\mathrm{x}}$ ) and partly from the nitrogen being present in the fuel $\left(\right.$ fuel $\left.\mathrm{NO}_{\mathrm{x}}\right)$. Thermal $\mathrm{NO}_{\mathrm{x}}$ is supposed to make up $70 \%$ or more of total $\mathrm{NO}_{\mathrm{x}}[18]$. Nevertheless, in our model, only the fuel $\mathrm{NO}_{\mathrm{x}}$ has to be considered, as only this kind of $\mathrm{NO}_{\mathrm{x}}$ is influenced by a fuel substitution. The change in $\mathrm{NO}_{\mathrm{x}}$ emission $\left(\Delta \mathrm{NO}_{\mathrm{x}}\right)$ is calculated in the same way as the $\Delta \mathrm{CO}_{2}$. For the conversion of $\mathrm{N}$ to $\mathrm{NO}_{\mathrm{x}}$, an individual conversion rate for every fuel is assumed. The conversion of fuel nitrogen to $\mathrm{NO}_{\mathrm{x}}$ depends on the kind of fuel and on the amount of nitrogen being present in the fuel. Considering the values of $1.3 \% \mathrm{~N}$ in coal and $0.44 \% \mathrm{~N}$ in heavy fuel oil (see Table 6 ), the conversion rate for coal is $35 \%$ and the rate for heavy fuel oil is $65 \%$ [19]. For waste solvents, we assume an average conversion rate of $85 \%$, which corresponds to the average conversion rate for $\mathrm{N}$ in light fuel oil [19]. The conversion rate, however, may be lower when the $\mathrm{N}$ content of the waste solvent is high. Furthermore, our model takes into account the fact that, with the plant mix of Table $4,50 \%$ of $\mathrm{NO}_{\mathrm{x}}$ are reduced on the average [7]. With this conversion rate, the $\mathrm{NH}_{3}$ slip is negligible [7], so $\mathrm{NH}_{3}$ emissions are not taken into account in our model. Eq. 10 quantifies the change in $\mathrm{NO}_{\mathrm{x}}$ emission $\left(\Delta \mathrm{NO}_{\mathrm{x}}\right.$ in $\left.\mathrm{kg} \mathrm{NO}_{\mathrm{x}}\right)$, considering that $1 \mathrm{~kg}$ of $\mathrm{N}$ gives $3.29 \mathrm{~kg} \mathrm{NO}_{\mathrm{x}}$ stoichiometrically.

$$
\begin{aligned}
& \Delta \mathrm{NO}_{\mathrm{x}}=\left(\mathrm{M}_{\text {waste solvent }} * \mathrm{~N}_{\text {waste solvent }} * \mathrm{R}_{\text {waste solvent }}-\mathrm{M}_{\text {coal }}\right. \\
& \left.* \mathrm{~N}_{\text {coal }} * \mathrm{R}_{\text {coal }}-\mathrm{M}_{\text {fuel oil }} * \mathrm{~N}_{\text {fuel oil }} * \mathrm{R}_{\text {fuel oil }}\right) * 0.5 * 3.29
\end{aligned}
$$

where

$\mathrm{N}$ is the nitrogen content in $\mathrm{kg} \mathrm{N} / \mathrm{t}$ fuel and $\mathrm{R}$ is the conversion rate in $\%$.
Other heteroatoms from the fuel such as $\mathrm{S}$ and $\mathrm{P}$ or the halogens are transferred and bound in the clinker to $100 \%$ [5]. Emissions of e.g. $\mathrm{SO}_{2}, \mathrm{P}_{2} \mathrm{O}_{5}$ or hydrogen halogenides are therefore not affected by a fuel substitution and were not included in our model. Note that this transfer of $100 \%$ is only valid for heteroatoms, which originate from the fuels. Heteroatoms that enter the kiln with the raw material have another fate and may cause atmospheric emissions. Emissions such as particulate matters, $\mathrm{CO}$ or volatile organic compounds are assumed not to be influenced by a fuel substitution with waste solvents, and were therefore not modelled.

When substituting conventional fuel with waste solvents a change in heavy metal emission can occur due to differences in heavy metal contents of the fuels. The 'delta'-emission created can either be negative or positive, depending on the heavy metal load of the waste solvent. To calculate the transfer of heavy metals into the flue gas, the transfer coefficients from Table 7 are used. The changes in heavy metal emissions $(\Delta \mathrm{HM}$ in $\mathrm{mg}$ ) are calculated with Eq. 11:

$$
\begin{aligned}
& \Delta \mathrm{HM}=\left(\mathrm{M}_{\text {waste solvent }} * \mathrm{HM}_{\text {waste solvent }}-\mathrm{M}_{\text {coal }} * \mathrm{HM}_{\text {coal }}\right. \\
& \left.-\mathrm{M}_{\text {fuel oil }} * \mathrm{HM}_{\text {fuel oil }}\right) * \mathrm{tc}_{\mathrm{i} \text {, flue gas }}
\end{aligned}
$$

where

$M$ is the mass of fuel in $t$, HM is the heavy metal content in $\mathrm{mg} / \mathrm{t}$ fuel, tc is the transfer coefficient for heavy metals into the flue gas and $\mathrm{i}$ is the respective heavy metal element.

\section{Application of the Method to a Case Study}

\subsection{Goal and scope}

To illustrate the applicability of our multi-input allocation model and to discuss quality and uncertainties of the model, we applied the model in a case study. For this purpose, four hypothetical waste solvents were assumed with a broad spectrum of properties (Table 8). First, a waste solvent with a high net calorific value and a low grade of impurity was chosen (pure toluene). This waste solvent represents a 'best case fuel substitute'. As a 'worst case fuel substitute', a waste solvent with a rather low net calorific value and the maximum amount of pollutants (according to Table 1 ) was chosen (ethanol loaded with heavy metals). The third waste solvent represents a solvent mixture which, alternatively to the use as fuel in clinker production, could be recycled by distillation (ethyl acetate mixed with $5 \%$ water). The fourth solvent is a chlorinated solvent with, according to Holcim AG standards, a maximum load of chlorine (butanol with $1 \%$ methylene chloride). Net calorific values for the solvents were taken from [20]. The functional unit is the use of one tonne of waste solvent as an alternative fuel for clinker production in Switzerland. 
Table 8: Elementary composition and net calorific values of the four theoretical waste solvents

\begin{tabular}{l|c|c|c|c|c}
\hline Substance / NCV & Unit & Toluene & $\begin{array}{c}\text { Ethanol with traces of } \\
\text { heavy metals }\end{array}$ & $\begin{array}{c}\text { Mixture of 95\% ethyl } \\
\text { acetate and 5\% water }\end{array}$ & $\begin{array}{c}\text { 99\% 1-butanol with 1\% } \\
\text { methylene chloride }\end{array}$ \\
\hline $\mathrm{C}$ & $\mathrm{kg} / \mathrm{t}$ & 913 & 522 & 518 & 643 \\
\hline $\mathrm{H}$ & $\mathrm{kg} / \mathrm{t}$ & 87 & 130 & 86 & 134 \\
\hline $\mathrm{O}$ & $\mathrm{kg} / \mathrm{t}$ & - & 348 & 346 & 214 \\
\hline $\mathrm{H} \mathrm{O}$ & $\mathrm{kg} / \mathrm{t}$ & - & - & 50 & - \\
\hline $\mathrm{Cl}$ & $\mathrm{kg} / \mathrm{t}$ & - & - & - & 9 \\
\hline $\mathrm{Cu}$ & $\mathrm{g} / \mathrm{t}$ & - & 100 & - & - \\
\hline $\mathrm{Ni}$ & $\mathrm{g} / \mathrm{t}$ & - & 100 & - & - \\
\hline $\mathrm{Zn}$ & $\mathrm{g} / \mathrm{t}$ & - & 400 & - & - \\
\hline $\mathrm{Net}$ calorific value & $\mathrm{MJ} / \mathrm{t}$ & 40,500 & 26,900 & 22,230 & \\
\hline & & & &
\end{tabular}

\subsection{Life cycle inventory analysis}

The specific LCIs were calculated with Equations 4, 5 and 8-11. Data for fuel properties and transfer coefficients were taken from Tables 5 to 7 . The results are presented as 'avoided input' and 'changes in output' in Table 9. The numbers in brackets in Table 9 refer to the gross emissions of solvent incineration. The incineration of one tonne of toluene, for instance, produces emissions of $3,350 \mathrm{~kg}$ of $\mathrm{CO}_{2}$. Subtracting the emissions saved from fuel substitution $(3,960 \mathrm{~kg} \mathrm{CO}$ ) leads to net $\mathrm{CO}_{2}$ emissions of $610 \mathrm{~kg}\left(\Delta \mathrm{CO}_{2}\right.$ in Table 9).

The amount of substituted fossil fuels depends on the net calorific value of the waste solvent under study. One tonne of toluene (net calorific value of $40,500 \mathrm{MJ} / \mathrm{kg}$ ) substitutes $1.22 \mathrm{t}$ of coal and $0.22 \mathrm{t}$ of heavy fuel oil. By contrast, one tonne of the ethyl acetate/water mixture (calculated effective net calorific value of 22,105 $\mathrm{MJ} / \mathrm{kg}$ ) substitutes only $0.67 \mathrm{t}$ of coal and $0.12 \mathrm{t}$ of heavy fuel oil. The proportion of coal to heavy fuel oil is constant for all waste solvents.

In all four cases, the fuel substitution leads to savings in $\mathrm{CO}_{2}$ emissions (shown by a negative value). The respective amount depends on the $\mathrm{C}$ content and on the net calorific value of the waste solvent. This effect can be well observed in the case of the ethanol and the ethyl acetate. The $\mathrm{C}$ content of the two solvents is similar $(52.2 \%$ and $51.8 \%$, respectively), but the effective net calorific value differs $(26,900 \mathrm{MJ} / \mathrm{t}$ and 22,105 MJ/t, respectively). The higher $\mathrm{C}$ content and the higher net calorific value lead to savings in $\mathrm{CO}_{2}$ emission, which are almost three times higher for ethanol than for ethyl acetate $(-715 \mathrm{~kg}$ and $-261 \mathrm{~kg}$, respectively). $\mathrm{NO}_{\mathrm{x}}$ emissions are also saved in all four cases. This results from the fact that none of the waste solvents under study contains N. The chlorine from butanol/ methylene chloride does not appear in the LCI. That is because the transfer of chlorine to the atmosphere is zero in our model. Regarding the heavy metals, there is a reduction of emissions in nearly all cases when using waste solvent instead of fossil fuels. Only the case of ethanol loaded with the maximally allowed amount of heavy metals (according to Table 1) did the changes in emissions lead to a positive net effect for $\mathrm{Cu}, \mathrm{Ni}$, and $\mathrm{Zn}$. To summarize, we can deduce from the inventory data that the incineration of solvents clearly leads to a net environmental benefit in all cases but one, in which the solvent was heavily contaminated with heavy metals. In this latter case, there is a trade off between additional heavy metal emissions from the solvent combustion and the impacts avoided through fuel substitution.

Table 9: $\mathrm{LCl}$ for the use of one tonne of waste solvent as alternative fuel for clinker production in Switzerland. The results are rounded to three relevant digits. The numbers in brackets refer to the gross fuel-related emissions from solvent incineration in the kiln, before subtraction of emissions avoided through the substitution of fossil fuels. Process-related emissions were not considered as they are independent of the fuel used

\begin{tabular}{|c|c|c|c|c|c|}
\hline Fuel / Emission & Unit & Toluene & $\begin{array}{c}\text { Ethanol with traces of } \\
\text { heavy metals }\end{array}$ & $\begin{array}{c}\text { Mixture of } 95 \% \text { ethyl acetate } \\
\text { and } 5 \% \text { water }\end{array}$ & $\begin{array}{l}99 \% \text { 1-butanol with } 1 \% \\
\text { methylene chloride }\end{array}$ \\
\hline \multicolumn{6}{|l|}{ Avoided Input } \\
\hline Coal & $\mathrm{t}$ & 1.22 & 0.81 & 0.67 & 1.00 \\
\hline Heavy fuel oil & $t$ & 0.22 & 0.15 & 0.12 & 0.18 \\
\hline \multicolumn{6}{|c|}{ Changes in Output } \\
\hline$\Delta \mathrm{CO}_{2}$ & $\mathrm{~kg}$ & $-610(3,350)$ & $-715(1,910)$ & $-261(1,900)$ & $-877(2,360)$ \\
\hline$\Delta \mathrm{NO}_{\mathrm{x}}$ & $\mathrm{kg}$ & -10.2 & -6.77 & -5.56 & -8.33 \\
\hline$\Delta$ As & $\mathrm{mg}$ & -3.69 & -2.45 & -2.02 & -3.02 \\
\hline$\Delta \mathrm{Cd}$ & $\mathrm{mg}$ & -31.7 & -21.1 & -17.3 & -25.9 \\
\hline$\Delta \mathrm{Cr}$ & $\mathrm{mg}$ & -5.29 & -3.51 & -2.89 & -4.32 \\
\hline$\Delta \mathrm{Cu}$ & $\mathrm{mg}$ & -4.60 & $+6.95(10.0)$ & -2.51 & -3.76 \\
\hline$\Delta \mathrm{Hg}$ & $\mathrm{mg}$ & -129 & -85.5 & -70.3 & -105 \\
\hline$\Delta \mathrm{Ni}$ & $\mathrm{mg}$ & -0.65 & $+0.57(1.00)$ & -0.35 & -0.53 \\
\hline$\Delta \mathrm{Pb}$ & $\mathrm{mg}$ & -362 & -240 & -197 & -296 \\
\hline$\Delta \mathrm{TI}$ & $\mathrm{mg}$ & -21.7 & -14.4 & -11.8 & -17.7 \\
\hline
\end{tabular}




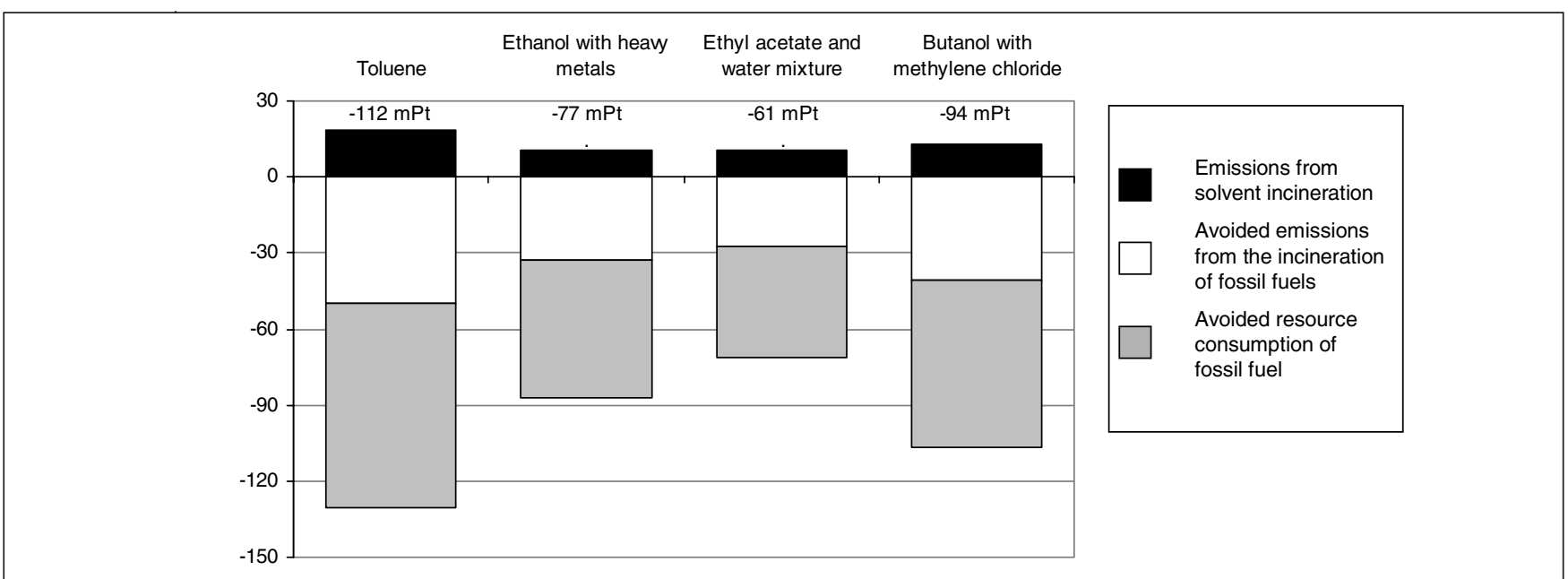

Fig. 4: Eco-profiles of the four waste solvents under study. Assessment method: Eco-Indicator 99, hierarchist type. Results are given in milli-Eco-points $(\mathrm{mPt})$. Only those fuel-related emissions were assessed that may change as a consequence of fuel substitution (Table 9)

\subsection{Life cycle impact assessment}

To evaluate the LCIs of the four solvents, the assessment method Eco-Indicator 99, hierarchist type, was used [21]. Here, we only show and discuss the aggregated results for reasons of brevity. All substances from the calculated LCIs (see Table 9), except for thallium, are covered by this assessment method. Background inventories for the fossil fuels were taken from [12]. For coal, the inventory "hard coal mix, at regional storage, UCTE" was applied and the inventory "heavy fuel oil, at regional storage, $\mathrm{CH}$ " was applied for heavy fuel oil.

In Fig. 4 the environmental impacts of the four waste solvents are shown. The results are subdivided in 'emissions from solvent incineration', 'avoided emissions from the incineration of fossil fuels', and 'avoided resource consumption of fossil fuels'. A negative value is equivalent to an avoided environmental impact (benefit), while a positive value means a negative environmental impact (burden).

The substitution of fossil fuels with waste solvents has a positive net effect on the environment (shown by a negative net environmental impact) concerning all four solvents. The extent of the effect depends on the properties of the waste solvents. With the assumed fuel mix (see Table 5), 49\% of the savings in fuel consumption come from coal and $51 \%$ from heavy fuel oil. Savings in $\mathrm{NO}_{\mathrm{x}}$ and $\mathrm{CO}_{2}$ dominate the net avoided emissions from the kiln (emissions of solvent incineration minus saved emissions of fossil fuel combustion). $\mathrm{NO}_{\mathrm{x}}$ makes up between $82 \%$ and $91 \%, \mathrm{CO}_{2}$ between 8 and $17 \%$ of the impacts of the net avoided emissions for the waste solvents under study. Heavy metals play a minor role in all of the examined waste solvents. The share of the avoided emissions lies between 0.3 and $1.1 \%$.

\subsection{Sensitivity analysis}

The solvents considered in this case study cover a broad spectrum of possible waste solvent properties and therefore represent the model in a reasonable way. In this section, we discuss the influence of the used model data (sensitivities). Model decisions and model uncertainties will be discussed in Section 5.
We expected one of the biggest sensitivities in the model to come from the fuel mix. Therefore, we looked at what happens, when only heavy fuel oil is substituted instead of the fuel mix. This case represents the present situation in the Swiss cement industry. On the one hand, heavy fuel oil is scarcer than coal (Eco-Indicator 99, hierarchist perspective, counts with $188 \mathrm{mPt} / \mathrm{t}$ for heavy fuel oil compared to 31.8 $\mathrm{mPt} / \mathrm{t}$ for coal; of these scores, $171 \mathrm{mPt}$ and $10.1 \mathrm{mPt}$, respectively, account for resource consumption). On the other hand, the net calorific value of fuel oil is higher than the net calorific value for coal $(40,400 \mathrm{MJ} / \mathrm{t}$ for heavy fuel oil compared to $25,800 \mathrm{MJ} / \mathrm{t}$ for coal). A substitution of heavy fuel oil therefore leads to a smaller total amount of substituted fossil fuels. Those two effects are opposite. Using Eco-indicator 99, hierarchist perspective, the net benefit of substituting the fuel mix was $-80.5 \mathrm{mPt}$ per t toluene and the net benefit of substituting heavy fuel oil was $-188 \mathrm{mPt}$. The fuel mix therefore appeared to be of importance if the Eco-indicator 99, hierarchist perspective, was used. Using the egalitarian perspective of Eco-indicator 99, we get similar results. By contrast, in the individualist perspective, resource consumption of fossil fuels is not accounted for. Therefore, the net benefit of substituting the fuel mix would be higher than that of substituting only oil.

The next aspect to be discussed is the variation in the net calorific values of the fossil fuels. In our model we used the average net calorific value for coal and heavy fuel oil from all five plants. The net calorific value of the heavy fuel oil only varies slightly (see Table 5). Calculations showed that the influence on the results is negligible (less than $1 \mathrm{mPt}$ per tonne of waste solvent). The net calorific value of coal varies more. The influence was between 11 and $23 \mathrm{mPt}$ per tonne of solvent for the minimum and maximum value. This uncertainty should be taken into account when using this model.

A further source of uncertainty comes from the composition of the fuels and from the transfer coefficients. Those influences will be discussed by looking at the emissions $\mathrm{CO}_{2}$, $\mathrm{NO}_{x}$ and heavy metals. As no information on the carbon content of the fuels was available from Holcim AG, pub- 
lished data were used. This is no problem for heavy fuel oil as the $\mathrm{C}$ content is relatively constant [13]. The carbon content of coal, however, varies more [22]. As the influence of coal is much larger than the influence of heavy fuel oil for the given fuel mix (mix of fossil fuels in our model: $85 \mathrm{w} \%$ coal and $15 \mathrm{w} \%$ heavy fuel oil), this parameter should be treated more carefully. A variation of the carbon content of $\pm 10 \%$ resulted in a change of $\mathrm{CO}_{2}$ emission of $\pm 1.7 \mathrm{mPt}$ for toluene (which is the waste solvent with the highest $\mathrm{C}$ content among the solvents considered here). Compared to the original environmental impact of $-3.4 \mathrm{mPt}$ for $\mathrm{CO}_{2}$ emissions, this is an effect of $\pm 50 \%$. Although the influence on the final result is not large in the study presented, this effect should not be neglected (especially when using assessment methods that put less weight on resource consumption).

$\mathrm{NO}_{\mathrm{x}}$ was seen to be an important parameter in the presented case study. This is, of course, also due to the fact that none of the waste solvents under study contain N. Principally, the same can be said for nitrogen as that which has already been discussed for carbon. Due to the higher proportion of coal in the fuel mix and due to a high variation in nitrogen content of coal [22], the nitrogen content of the coal is a sensitive parameter. Furthermore, little information is available on the $\mathrm{NO}_{x}$ formation (e.g. conversion rates) from fuel $\mathrm{N}$ in the cement production. In our case study, the share of $\mathrm{NO}_{\mathrm{x}}$ emission on the whole impact amounts to about $25 \%$. Therefore, nitrogen in coal should be regarded as a sensitive parameter.

With respect to heavy metals, waste solvents from chemical industry do not contain detectable amounts of the elements $\mathrm{As}, \mathrm{Cd}, \mathrm{Cr}, \mathrm{Hg}, \mathrm{Pb}$ and $\mathrm{Tl}$ [2]. Therefore, the savings for those elements are maximal. Toluene, which has the maximum substitution effect due to the high net calorific value, avoided an environmental impact of $-0.35 \mathrm{mPt}$ concerning the sum of all heavy metal emissions to air. For emissions of $\mathrm{Cu}, \mathrm{Ni}$ and $\mathrm{Zn}$ to air, the maximum effect was shown for ethanol $(0.12 \mathrm{mPt})$. Neither the transfer coefficients nor the variation in fuel composition show a variation that is expected to have a large influence on the heavy metal emission. We therefore expect no large influence on the final result from the heavy metal emissions to air. Emissions of heavy metals to water after clinker disposal were not quantified in this work. In the case study, such emissions would only increase the avoided impact since the substituted fossil fuels contained heavy metals while the solvents did not, except for the heavy metal contaminated ethanol. The general results would therefore only be reinforced. Concerning ethanol, the maximal additional impact would amount to $1.8 \mathrm{mPt}$, if it were assumed that all $\mathrm{Cu}$, $\mathrm{Ni}$, and $\mathrm{Zn}$ would be released from the clinker in the long run (worst-case assumption). This impact score is not significant with respect to the overall impact. Moreover, it would be compensated by the avoided emissions of such other metals as $\mathrm{As}, \mathrm{Cd}, \mathrm{Cr}, \mathrm{Hg}, \mathrm{Pb}$, and $\mathrm{Tl}$.

\section{Discussion}

The proposed model allows calculating inventory data from incinerating alternative fuels such as waste solvents in a clinker production kiln. Our aim was to depict the Swiss cement production landscape. Therefore, we chose to set up an average model representing the Swiss technology mix of clinker production processes. Alternatively, a technologyspecific model such as presented in [23] could have been developed. In such a model, plants are grouped in different classes according to the technology used. This allows a more flexible application with regard to other geographical regions with different technology mixes. However, in our case, such a technologically-specific model could not be developed because every plant had a unique combination of kiln technology and flue gas treatment technology so a grouping was not possible. A classification according to the kiln technology only (suspension preheater or Lepol) would have given a wrong representation as the flue gas treatment technologies have a larger influence on the transfer of pollutants than the kiln technology itself [7]. A classification according to the flue gas treatment technology was not taken into account since all gas purification systems differed from each other. Therefore, a modular model for different types of kilns and flue gas treatment technology could only have been set up on the basis of theoretical calculations [17], but not on measurement data, as used in this study.

Strictly spoken, our model is therefore only valid for the five Swiss plants of Holcim AG. However, the model can easily be applied for the whole of Switzerland, as the conditions are very similar for the other plants. When the model is used for other geographical regions, a fitting of the fuel mix and the coal composition might be necessary as those parameters are seen to have the largest influence in our model. If the technology used in the region under study is very different to the Swiss situation, the transfer coefficients for heavy metals might also have to be adjusted. For instance, when raw materials are processed that require special treatment of the flue gas (e.g. a scrubber) or when other kiln technologies predominate (e.g. more wet processes), this will influence the transfer coefficients.

Our model was only designed for waste solvents or similar wastes (liquid, low contamination). An extension of our model to other types of waste has to be done with caution because the incineration of some wastes, e.g. solids with high ash content, can influence the raw material input. In some cases, a substitution of raw materials is even the primary aim of using waste materials in clinker production. For instance, Jacobs [24] investigates the technical feasibility of substituting mineral materials in cement production, such as limestone or sand, with thermally treated slag from the incineration of municipal solid waste. LCA is a suitable tool to assess such substitution of natural resources with waste materials. However, the present model needs to be adapted before it can be used for solid waste materials, as the substitution of raw materials has not been considered in the current version.

Our model is based on linear relationships for the savings of fossil fuels and changes in emissions. Linear modelling is the state of the art in LCA for multi-input allocation modelling (e.g. [23]). Furthermore, we assumed that the composition of the waste solvent does not influence the transfer co- 
efficients. This is the common approach used for multi-input allocation modelling in LCA. In reality, the transfer of an element depends on other elements being present in the waste and on the chemical compound in which it is bound. However, since information about those interdependencies is not available, our approximation is to use constant transfer coefficients.

In order to roughly validate the transfer coefficients of our model, we compared them to transfer coefficients from municipal solid waste (MSW) incinerators. We chose MSW incinerators as a reference, as these have a similar gas purification system to the clinker kilns of Table 4: The flue gas cleaning technologies of the MSW grate incinerators we looked at ranged from electric precipitators only to modern gas purification systems with $\mathrm{SO}_{2}$-removal, DENOX, and active coke filter [23]. The average transfer coefficients of our model were within the range of values of transfer coefficients of waste incineration plants. Also the minimum transfer coefficients of below $0.1 \%$ seem to be plausible for plants with modern gas purification systems including active coke filter, for all elements considered.

The results from the case study showed that solvent incineration in clinker kilns generally has a net environmental benefit, at least if the heating value (and therefore the amount of substituted fossil fuel) is sufficiently high and the pollutant content is small. This is fortunate, although it would be rash to conclude that all chemical solvents should be incinerated in cement kilns. This is because the regeneration of solvents or the incineration in special waste solvent incinerators may also lead to net environmental benefits, as has been shown in case studies [2,25]. To identify the optimal waste solvent management strategy, further models for other treatment and recycling options of waste solvents are needed. One such model for solvent incineration in special solvent incineration plants has already been set up [2]. Another model for the regeneration of solvents from mixtures is currently under development. The final goal is to provide a set of tools that help the chemical industry to decide which waste management strategy is most suitable for a given (mixture of) waste solvent. The model presented in this paper is one building brick towards this goal.

\section{References}

[1] Bruder C (2000): Abfall-Lösungsmittelmanagement in der chemisch-pharmazeutischen Industrie. Diploma thesis at the Swiss Federal Institute of Technology Zurich. Zurich: Eidgenössische Technische Hochschule Zürich

[2] Seyler C (2003): Life Cycle Inventory for Thermal Treatment of Waste Solvent from Chemical Industry: A Multi-Input Allocation Model. Journal of Cleaner Production, accepted for publication

[3] cemsuisse (2002): Kennzahlen 2002. Bern, cemsuisse

[4] Künniger T, Werner F, Richter K (2001): Ökologische Bewertung von Kies, Zement und Beton in der Schweiz (Kurzfassung). Forschungs- und Arbeitsbericht 115/45, EMPA Abteilung 115, Gruppe Ökologie. Dübendorf, Switzerland, EMPA
[5] BUWAL (1997): Abfallentsorgung in Zementwerken - Thesenpapier. Umwelt-Materialien Nr. 70. Bern: BUWAL

[6] BUWAL (1998): Richtlinie zur Entsorgung von Abfällen in Zementwerken. Bern: BUWAL

[7] Holcim (Schweiz) AG (2003): Internal communication. Würenlingen: Holcim (Schweiz) AG

[8] Liebl P, Gerger W (1993): Nutzen und Grenzen beim Einsatz von Sekundärstoffen. Zement-Kalk-Gips 46 (10) 632-638

[9] Duda WH (1985): Cement-Data-Book. 3rd edition. Wiesbaden und Berlin: Bauverlag $\mathrm{GmBH}$

[10] Van Oss HG, Padovani AC (2002): Cement Manufacture and the Environment - Part I: Chemistry and Technology. Journal of Industrial Ecology 6 (1) 89-155

[11] Ernst Basler \& Partner AG (1998): Einsatz von Trockenklärschlamm in der Schweizer Zementindustrie - Ökonomische und ökologische Grundlagen. Zürich: Ernst Basler \& Partner AG

[12] Swiss Centre for Life Cycle Inventories (2003): ecoinvent 2000 $<$ http://www.ecoinvent.ch>

[13] Gumz W (1962): Kurzes Handbuch der Brennstoff- und Feuerungstechnik. 3rd edition. Berlin, Springer-Verlag

[14] Beitz W, Küttner KH (1987): Dubbel - Taschenbuch für den Maschinenbau. 16th edition. Berlin: Springer-Verlag

[15] Petroplus (2003): Personal communication with K. Baumann, Petroplus Marketing AG, Zug, Switzerland

[16] Belevi H (1998): Environmental Engineering of Municipal Solid Waste Incineration. Habilitation thesis at the Swiss Federal Institute of Technology Zurich. Zurich, Eidgenössische Technische Hochschule Zürich

[17] Dr. Graf AG (1998): Regelung über die Abfallentsorgung in Zementwerken - Grundlagen, Methoden, Berechnungen. Bericht 91.2018/A, Auftraggeber: BUWAL. Gerlafingen, Switzerland, Dr. Graf AG

[18] Van Oss HG, Padovani AC (2003): Cement Manufacture and the Environment - Part II: Environmental Challenges and Opportunities. Journal of Industrial Ecology 7 (1) 93-125

[19] Baumbach G (1993): Luftreinhaltung. 3rd edition. Berlin, Springer-Verlag

[20] Smallwood IM (1996): Handbook of Organic Solvent Properties. London, Edward Arnold Publ. Ltd.

[21] Goedkoop M, Spriensma R (1999): The Eco-Indicator 99: A damage oriented method for life cycle impact assessment: Methodology report. Amersfoort, The Netherlands, Pré Consultants bv

[22] Ruhrkohlen-Handbuch (1987): Ruhrkohlen-Handbuch Anhaltszahlen, Erfahrungswerte und praktische Hinweise für industrielle Verbraucher. $7^{\text {th }}$ edition. Essen, Glückauf $\mathrm{GmbH}$ Verlag

[23] Hellweg S, Hofstetter TB, Hungerbühler K (2001): Modeling waste incineration for life-cycle inventory analysis in Switzerland. Environmental Modeling and Assessment 6 (4) 219-235

[24] Jacobs F (2003): Secondary raw materials from waste. In: Ludwig C, Hellweg S, Stucki S, Municipal Solid Waste management, Strategies and technologies for sustainable solutions, Springer, Berlin-Heidelberg-New York, 109-121

[25] Hofstetter TB, Capello C, Hungerbühler K (2003): Environmentally Preferable Treatment Options for Industrial Waste Solvent Management: A Case Study of a Toluene Containing Waste Solvent. Transactions of the Institution of Chemical Engineers 81 (3) 189-202

Received: November 7th, 2003

Accepted: August 11th, 2004 OnlineFirst: August 21st, 2004 